\title{
Sources of variation and genetic profile of spontaneous, out-of-season ovulatory activity in the Chios sheep
}

\author{
Melpomeni Avdi ${ }^{\mathrm{a} *}$, Georgios BAnOs ${ }^{\mathrm{b}}$, \\ Athanasios Kouttos $^{\mathrm{a}}$, Loys Bodin ${ }^{\mathrm{c}}$, Philippe CHemineau $^{\mathrm{d}}$ \\ a Faculty of Agriculture, Aristotle University of Thessaloniki, \\ 54124 Thessaloniki, Greece \\ ${ }^{\mathrm{b}}$ Faculty of Veterinary Medicine, Aristotle University of Thessaloniki, \\ 54124 Thessaloniki, Greece \\ c Inra, 31326 Castanet-Tolosan, France \\ ${ }^{\mathrm{d}}$ Inra, 37380 Nouzilly, France
}

(Received 11 February 2002; accepted 13 August 2002)

\begin{abstract}
Organising the breeding plan of a seasonally breeding species, such as sheep, presents a challenge to farmers and the industry as a whole, since both economical and biological considerations need to be carefully balanced. Understanding the breeding activity of individual animals becomes a prerequisite for a successful breeding program. This study set out to investigate the sources of variation and the genetic profile of the spontaneous, out-of-season ovulatory activity of ewes of the Chios dairy sheep breed in Greece. The definition of the trait was based on blood progesterone levels, measured before exposing the ewes to rams, which marks the onset of the usual breeding season. Data were 707 records, taken over two consecutive years, of 435 ewes kept at the Agricultural Research Station of Chalkidiki in northern Greece. When all available pedigree was included, the total number of animals involved was 1068 . On average, $29 \%$ of all ewes exhibited spontaneous, out-of-season ovulatory activity, with no substantial variation between the years. Significant sources of systematic variation were the ewe age and live weight, and the month of previous lambing. Older, heavier ewes, that had lambed early the previous autumn, exhibited more frequent activity. Heritability estimates were 0.216 $( \pm 0.084)$ with a linear and 0.291 with a threshold model. The latter better accounts for the categorical nature of the trait. The linear model repeatability was $0.230( \pm 0.095)$. The results obtained in this study support the notion that spontaneous out-of-season ovulatory activity can be considered in the development of a breeding plan for the Chios sheep breed.
\end{abstract}

reproduction / genetic parameter / sheep / ovulatory activity

\footnotetext{
* Correspondence and reprints
}

E-mail: avdimel@agro.auth.gr 


\section{INTRODUCTION}

In temperate latitudes, the sheep is one of the best examples of a seasonally breeding species. Several researchers have shown differences in the duration of the breeding season of sheep raised in the same region [1,24]. The principal mechanism that triggers the onset of the breeding season relates to light. Thus, naturally, sheep mainly breed in the autumn, when the duration of daylight decreases and give birth in early spring. In extensive and semi-intensive production systems, this mechanism protects the lambs from the winter and allows them to grow in more favourable conditions. Seasonality, however, presents an organisational challenge to farmers and the sheep industry as a whole, as cost related issues and the demand for constant supply of animal products need to be balanced against the biological aspects of the animal.

In Greece, where the majority of sheep are kept in extensive and semiintensive conditions, farmers wish to effectively organise the breeding season and group lambing, to minimise their production costs while meeting the market demands. Hormonal and/or photoperiodic treatments [2-4] have been used successfully to induce oestrous, but they are expensive and their effect disappears when the treatments end. Furthermore, they are not consistent with consumer demands for the reduction of hormones, antibiotics and other substances. Another approach to induce oestrous has been to expose ewes to rams. The so-called "ram effect" is a social stimulus that acts to advance the onset of the breeding season in sheep and goats. However, the duration of the anoestrus period or the presence of already cyclic ewes [18] may limit the success.

The genetic component of sexual activity has long been considered a potential approach to control the onset of the breeding season [12,16,22]. Hanocq et al. [11] considered spontaneous, out-of-season ovulatory activity as such a trait and reported high heritability and repeatability estimates $(0.37$ and 0.20 , respectively) for the Mérinos d'Arles breed.

The Chios breed in Greece is a dairy sheep breed with considerable economic interest, mainly due to its high prolificacy and production. Avdi et al. [1] studied its seasonality and observed a relatively high proportion of ewes ovulating outside the normal breeding season, with some ewes maintaining a spontaneous, out-of-season ovulatory activity for over 2 consecutive years.

The objective of this study was to examine the sources of variation and the genetic profile of spontaneous, out-of-season ovulatory activity in the Chios sheep breed.

\section{MATERIALS AND METHODS}

\subsection{Animal population description}

The Chios breed is a dairy sheep breed of considerable economic interest to Greek farmers. Ewes give birth to an average of 1.8 lambs, which suckle 
for 42 days and are then slaughtered at $15 \mathrm{~kg}$ live weight. The ewes are subsequently milked for $4-5$ months and produce an average of $200 \mathrm{~kg}$ milk per lactation.

The ewes of the Chios breed that are kept at the Agricultural Research Station of Chalkidiki in northern Greece $\left(40^{\circ} 15^{\prime \prime} \mathrm{N}\right)$ were studied. This is a closed flock that belongs to the National Agricultural Research Institute of Greece. The animals are mostly kept in open barns. Feeding is mainly based on concentrates, dry clover and grazing.

The reproductive season normally starts on May 21st and lasts until late November. The onset of the season is marked by the introduction of males and the exposure of the females to the so-called "ram effect". Mating is always by natural service in a circular pattern that was designed to keep inbreeding under control. No hormonal, light or other treatment is involved during mating. Lambing takes place between late October and April, with about $40 \%$ of all lambings occurring in November. Replacement selection is based on pedigree and own phenotypic performance.

\subsection{Trait definition}

The same procedure of determining spontaneous ovulatory activity, as described in a study of the Mérinos d'Arles sheep in France [11], was followed. Briefly, spontaneous ovulatory activity was determined by investigating the blood progesterone level in ewes prior to introducing rams to the flock i.e., before the onset of the normal breeding season. Blood samples were taken twice at a 10-day-interval in the beginning of May, for two consecutive years (1996 and 1997). The samples were centrifuged $\left(3000 \mathrm{r} \cdot \mathrm{min}^{-1}\right.$ for $15 \mathrm{~min}$ at the Laboratory of Animal Reproduction, Aristotle University of Thessaloniki, Greece) and the plasma was frozen at $-20{ }^{\circ} \mathrm{C}$ and transported to the Laboratory of Hormonal Analysis at the National Agricultural Research Institute in Nouzilly, France. Plasma progesterone levels were measured by radioimmunoassay [23]. The ewes whose progesterone concentration was higher than $1 \mathrm{ng} \cdot \mathrm{mL}^{-1}$ in one or two samples were considered to be in ovulatory activity.

\subsection{Data}

A total of 707 records of spontaneous, out-of-season ovulatory activity expressed as binary measures ( 0 inactivity, 1 activity) were considered in the analysis. The records were of 435 ewes, daughters of 150 sires. Amongst these ewes, 272 were sampled in both years, 92 were sampled in year 1 only, and 71 were sampled in year 2 only. These ewes were subsequently exposed to rams for natural mating in a ratio of 15:1. Thus, 364 and 343 ewes were present at mating during the first and second year of the study, respectively. 
All available pedigree information was considered in the analysis and the total data set included 1068 animals.

\subsection{Statistical models and genetic analysis}

Preliminary analysis of variance indicated that the following factors had a significant effect on the variation of spontaneous out-of-season ovulatory activity: age, live weight and month of previous lambing [13]. The interactions between these effects were not significant. Consequently, three main fixed effects were defined for the genetic analysis. The first effect represented the age and status of the ewe, and had seven levels corresponding to young ewes that had never lambed before (level 1), the ewes that had lambed before but not in the previous season (level 2), and the ewes that lambed for the first, second, third, fourth and fifth or greater time in the previous season (levels $3-7$, respectively). The second effect represented live weight and had six levels defined by five thresholds at $50,55,60,65$ and $70 \mathrm{~kg}$, respectively. The third effect was the month of previous lambing and had 6 levels for October, November, December, January, February, and March and April combined. This last effect was related to the impact of the post-partum interval on ovulatory activity.

It should be noted here that all ewes, whether they had exhibited spontaneous out-of-season ovulatory activity or not during the previous season, were exposed to the rams at the same time. Non-seasonal breeders were not offered an early chance at mating. Hence, no confounding between spontaneous outof-season ovulatory activity and month of previous lambing should be expected in this data. Two models were considered for the data analysis: a linear model, assuming normally distributed records and a theoretically more accurate nonlinear threshold model, assuming an underlying normally distributed liability scale of the observed binary $(0,1)$ variable. The linear model was first used to estimate heritability and repeatability. With this model it was possible to separately include the individual animal and permanent environmental effects, and all available genetic relationships. The following linear model was fitted:

$$
\mathrm{Y}_{i j k l m}=\mu+\mathrm{age}_{i}+\text { weight }_{j}+\operatorname{month}_{k}+\operatorname{animal}_{l}+\mathrm{pe}_{l m}+\mathrm{e}_{i j k l m}
$$

where:

$\mathrm{Y}=$ spontaneous out-of-season ovulatory activity record $(0,1)$;

$\mu \quad=$ overall mean;

age $\quad=$ fixed effect of the $i$ th age of the ewe class;

weight $=$ fixed effect of the $j$ th weight of the ewe class;

month $=$ fixed effect of the $k$ th calendar month of the previous lambing class;

animal $=$ random effect of the $l$ th ewe $\left(\right.$ Variance $\left.=V_{a}\right)$; 
pe $\quad=$ random effect of the permanent environment of the $l$ th ewe (Variance $=V_{p e}$ );

e $\quad=$ random residual effect (Variance $=V_{e}$ ).

All random factors were assumed to be normally distributed with mean zero and the variance shown above. The between-animal variance $\left(V_{a}\right)$ was considered equivalent to the genetic variance with an expected structure defined by the numerator relationship matrix between all 1068 animals. The three variance components were estimated using an Average Information Restricted Maximum Likelihood $[9,10]$. Genetic parameters, namely heritability $\left(h^{2}\right)$ and repeatability $(r)$, were calculated from the estimated variance components as follows:

$$
h^{2}=\frac{V_{a}}{V_{a}+V_{p e}+V_{e}} \quad r=\frac{V_{a}+V_{p e}}{V_{a}+V_{p e}+V_{e}} .
$$

The non-linear threshold model was considered to estimate heritability on the underlying scale. Threshold models are theoretically more appropriate for the analysis of binary data, assuming that the observed values are associated with an underlying variable that is normally distributed [8]. Due to computational limitations, a sire effect was fitted in this model. Sires were required to have at least two daughters with records and a subset of 615 observations was formed. All genetic relationships between sires were considered (total of 200 animals). The model used for the analysis was:

$$
\mathrm{Y}_{i j k l m}=\mu+\mathrm{age}_{i}+\text { weight }_{j}+\text { month }_{k}+\text { sire }_{l}+\mathrm{e}_{i j k l m}
$$

where:

$\mathrm{Y}=$ the underlying variable associated with the spontaneous, out-ofseason ovulatory activity record;

$\mu$, age, weight, month $=$ fixed effects as defined in Model 1;

sire $=$ random effect of the $l$ th sire of the $m$ th ewe $\left(\right.$ Variance $\left.=V_{s}\right)$;

$\mathrm{e} \quad=$ random residual effect $\left(\right.$ Variance $\left.=V_{e}\right)$.

The between-sire variance $\left(V_{s}\right)$ was considered equivalent to one quarter of the genetic variance with the expected structure including the numerator relationship matrix between the 200 sires. Variance components were estimated using CMMAT2 [15]. Heritability for the underlying variable associated with spontaneous ovulatory activity was calculated as follows:

$$
h_{l}^{2}=\frac{4 V_{s}}{V_{s}+V_{e}} .
$$

This value may be related to the heritability measured on the observed scale $\left(h^{2}\right)$ with the expression proposed by Robertson and Lerner [21]:

$$
h_{l}^{2}=\frac{h^{2} z^{2}}{p(1-p)}
$$


where $z$ is the value of the density of the underlying distribution at the threshold point $p$, corresponding to the percentage of ewes in ovulatory activity.

\section{RESULTS}

\subsection{Descriptive statistics}

The frequency of spontaneous, out-of-season ovulatory activity in these data is shown in Table I. On average, 29\% of the ewes exhibited spontaneous ovulatory activity in early May in 1996 and 1997.

Of the 435 ewes considered in this study, 272 had records in both years. About $16 \%$ of the latter (44 ewes) exhibited spontaneous out-of-season ovulatory activity in both years, suggesting a possibly repeatable trait (Tab. II). It is also worth noting that of those ewes that showed ovulatory activity in the first year $(37+44=81), 54 \%$ (44 ewes) also showed an activity in the second year.

\subsection{Sources of variation}

The significant $(P<0.05)$ effect of the ewe's age on the spontaneous, outof-season ovulatory activity is shown in Figure 1. The effect was considerably early in the ewe's life, with an increase of about $20 \%$ on ovulatory activity between young ewes about to be mated for the first time and ewes that had lambed for the third time in the previous season.

The significant $(P<0.05)$ effect of previous lambing month on the spontaneous, out-of-season ovulatory activity is shown in Figure 2. This effect represents the time elapsed since the ewe's previous lambing, before testing for ovulatory activity. There was a considerable difference between the ewes which had lambed in October (i.e., about 6 months before the test) and those

Table I. Number of ewe records used in the analysis.

\begin{tabular}{lccc}
\hline & 1996 & 1997 & overall \\
\hline Number of ewe records & 364 & 343 & 707 \\
\% showing spontaneous ovulatory activity & 30.2 & 27.1 & 29.0 \\
\hline
\end{tabular}

Table II. Spontaneous ovulatory activity in ewes with repeated measures in two years.

\begin{tabular}{lrr}
\hline Number of ewes & 272 & $100 \%$ \\
No activity & 154 & $56.6 \%$ \\
Activity in Year 1 only & 37 & $13.6 \%$ \\
Activity in Year 2 only & 37 & $13.6 \%$ \\
Activity in both years & 44 & $16.2 \%$ \\
\hline
\end{tabular}




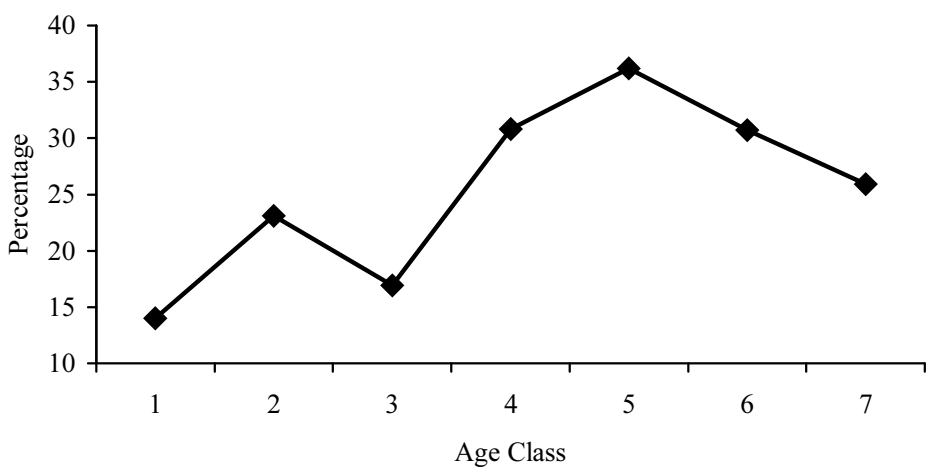

Figure 1. Linear model solutions for age effect on spontaneous, out-of-season ovulatory activity; $1=$ young ewes that had never lambed before; $2=$ older ewes that had not lambed in previous season; 3, 4, 5, 6, $7=$ ewes that lambed for the 1st, 2nd, 3rd, 4 th, and 5 th or greater time, respectively, in the previous season.

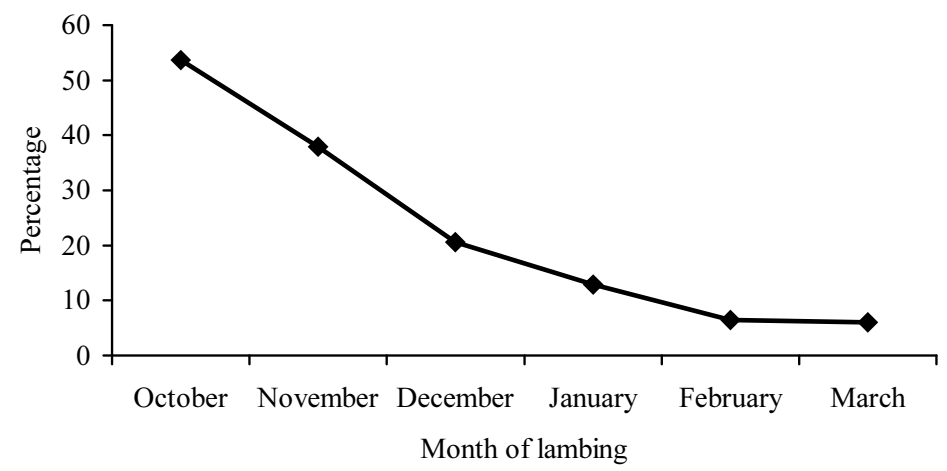

Figure 2. Linear model solutions for the month of previous lambing effect on spontaneous, out-of-season ovulatory activity.

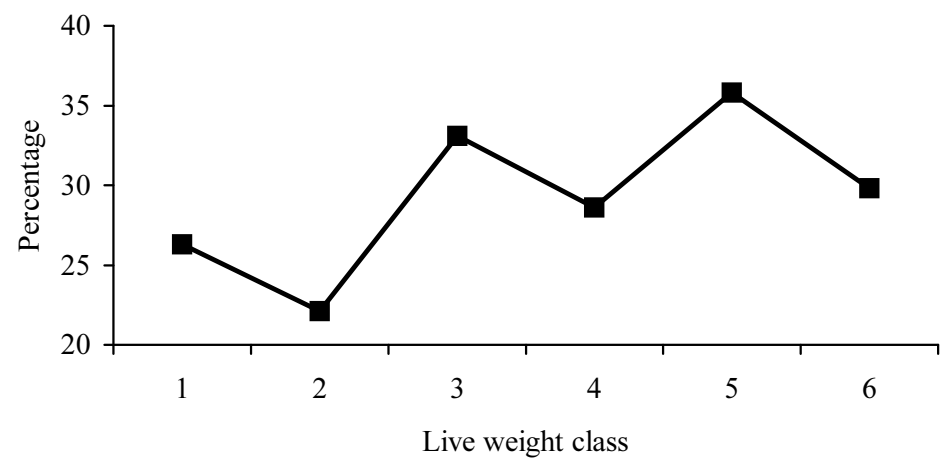

Figure 3. Linear model solutions for live weight at heat effect on the spontaneous outof-season ovulatory activity; $1 \leqslant 50 \mathrm{~kg}, 2=50-54 \mathrm{~kg}, 3=55-59 \mathrm{~kg}, 4=60-64 \mathrm{~kg}$, $5=65-69 \mathrm{~kg}, 6 \geqslant 70 \mathrm{~kg}$. 
Table III. Genetic parameter estimates of spontaneous, out-of-season ovulatory activity in the Chios sheep from linear and threshold model analysis; standard errors in parenthesis.

\begin{tabular}{lccc}
\hline Model & Number of observations & Heritability & Repeatability \\
\hline Linear animal model & 707 & $0.216(0.084)$ & $0.230(0.095)$ \\
Threshold sire model & 615 & 0.291 & \\
\hline
\end{tabular}

lambing in February/March (i.e., 2-3 months before the test), with the former showing almost $40 \%$ higher ovulatory activity rates than the latter.

The significant $(P<0.05)$ effect of the ewe's live weight on the spontaneous, out-of-season ovulatory activity is shown in Figure 3. Heavier ewes had, in general, higher rates of ovulatory activity (adjusted for age). The largest difference observed was $14 \%$ between the $65-69 \mathrm{~kg}$ and the $50-54 \mathrm{~kg}$ class.

\subsection{Genetic parameters}

Heritability and repeatability estimates of spontaneous, out-of-season ovulatory activity from linear and threshold models are shown in Table III. Threshold model heritability (0.291) was slightly higher than the heritability obtained with the linear model $(0.216 \pm 0.084)$. The former was also close to the estimate $(0.32)$ obtained from the formula proposed by Robertson and Lerner [21].

\section{DISCUSSION}

In this study, 29\% of the Chios breed ewes examined exhibited spontaneous, out-of-season ovulatory activity in early May, as determined by blood progesterone levels. The data from two consecutive years were considered, with very little year variation across. This result was very consistent with a study of the Mérinos d'Arles breed [11] reporting a 28\% rate of spontaneous out-of-season ovulatory activity, determined in the same way. The high proportion of ewes cycling out-of-season presents the opportunity to better manage the breeding period and reproduction of the flock.

In this study, a significant variation in the spontaneous, out-of-season ovulatory activity in the Chios breed was caused by the ewe's age and live weight, and the post-partum interval since the previous lambing. The effect of age was significant, especially on young ewes. Ovulatory activity increased with age but started decreasing after the ewe had her third lambing. The results were consistent with those reported by Hanocq et al. [11] for the Mérinos d'Arles breed. 
Live weight also had a positive effect on the trait, with larger weights (65-69 kg) being associated with more frequent spontaneous out-of-season ovulatory activity. Similar observations were made by Hanocq et al. [11] in the Mérinos d'Arles breed.

Month of previous lambing, representing the time elapsed between lambing and testing for ovulatory activity, had a significant effect. The highest rates of the spontaneous out-of-season ovulatory activity were observed in the ewes that had the longest periods between lambing and testing and the lowest for those that had most recently lambed. This agrees with the results of Dzabirski and Notter [5], who reported a significant effect of time since the last lambing on sexual activity, when comparing autumn and winter lambings. Furthermore, the winter lambings in the Dzabirski and Notter [5] study took place only 3-4 months prior to assessing the blood progesterone level, to determine whether the ewes were cycling. Hence, the ewes that had lambed in the winter did not have enough time to recover and commence sexual activity.

The genetic profile of spontaneous, out-of-season ovulatory activity of the Chios sheep breed was also examined. Heritability estimates of 0.216 and 0.291 were obtained with a linear and threshold model, respectively. The threshold model estimate was higher than the linear model's, in accordance with theory [7] and the categorical nature of the trait under investigation. Furthermore, the threshold model estimate was similar to the expected heritability value obtained by the Robertson and Lerner [21] formula. In the only other study of spontaneous, out-of-season ovulatory activity as measured here, Hanocq et al. [11] reported very similar heritability estimates for the Mérinos d'Arles sheep breed. These estimates suggest that spontaneous, out-of-season ovulatory activity can be subject to successful genetic selection. Heritability estimates of other seasonal fertility traits have been found between 0.20 and $0.35[6,20]$ whereas heritability estimates of $0.07-0.34$ have been reported for traits related to out-of-season lambing [14,17]. Despite the wide range of estimates largely due to differences in data, breeds and trait definition, sheep fertility appears to be heritable and, therefore, may be improved with selective breeding.

The repeatability estimate of the spontaneous, out-of-season ovulatory activity obtained from the linear model analysis was 0.23 . This value is very close to the heritability estimate obtained in the same analysis, indicating that the source of the estimated repeatability is mainly genetic. The fact that more than half of the ewes that exhibited spontaneous, out-of-season ovulatory activity in the first year also exhibited it in the second suggests that the trait is, indeed, repeatable.

The results obtained in this study confirm the presence of genetic and heritable variation in spontaneous, out-of-season ovulatory activity in the Chios breed. The mode of inheritance of the trait, however, deserves further 
investigation. In this study, the data were analysed with infinitesimal models. These models assume additive, equally small effects of an infinite number of genes controlling the trait in question. Our data were not suitable for further analysis, such as segregation analysis, which might indicate the presence or absence of oligogenic inheritance. However, it would be desirable to test the infinitesimal model hypothesis, with additional data and a careful design, and search for genes with a potentially major effect on the trait. In a recent study [19], an association was found between the structure of the melatonin receptor gene and out-of-season ovulatory activity in the Mérinos d'Arles breed. There would be scope for research on the role of the melatonin gene in the breeding behaviour of the Chios sheep.

\section{CONCLUSION}

Spontaneous, out-of-season ovulatory activity, determined by blood progesterone levels, can be considered in the development of a breeding plan for the Chios sheep breed that would cater to the needs of the farmers and market demands. There appears to be considerable scope for selective breeding and genetic improvement for this trait. Further study is required to investigate the exact mode of inheritance and possible presence of a major gene.

\section{ACKNOWLEDGEMENTS}

The authors wish to thank the staff in charge of the Chios flock in NAGREFChalkidiki, the General Directory of NAGREF in Athens and the RIA laboratory in Nouzilly (France) for performing the progesterone assays. The availability of A. Gilmour's ASREML and I. Misztal's CMMAT2 computer programmes for statistical analysis is gratefully acknowledged.

\section{REFERENCES}

[1] Avdi M., Driancourt M.A. Chemineau P., Variations saisonnières du comportement d'oestrus et de l'activité ovulatoire chez les brebis Chios et Serres en Grèce, Reprod. Nutr. Dev. 33 (1993) 15-24.

[2] Bodin L., Drion P.V., Remy B., Brice G, Cognie Y., Beckers J.F., Anti-PMSG antibody levels in sheep subjected annually to oestrus synchronisation, Reprod. Nutr. Dev. 37 (1997) 651-660.

[3] Chemineau P., Malpaux B., Pelletier J., Leboeuf B., Delgadillo J.A., Deletang F., Pobel T., Brice G., Emploi des implants de mélatonine et des traitements photopériodiques pour maîtriser la reproduction saisonnière chez les ovins et les caprins, Inra Prod. Anim. 9 (1996) 45-60. 
[4] Cognie Y., Nouvelles méthodes utilisées pour améliorer les performances de reproduction chez les ovins, Inra Prod. Anim. 1 (1988) 83-92.

[5] Dzabirski V., Notter D.R., Effects of breed and time since lambing on spring oestrous activity in mature ewes, Anim. Reprod. Sci. 19 (1989) 99-108.

[6] Fahmy M.H., Genetic parameters of date of lambing in "DLS" sheep, in: Barton R.A., Smith W.C. (Eds.), Proc. World Congr. on Sheep and Beef Cattle Breeding, Palmerston North, New Zealand, 1982, pp. 410-404.

[7] Gianola D., Theory and analyses of threshold characters, J. Anim. Sci. 54 (1982) 1076-1096.

[8] Gianola D., Foulley J.L., Sire evaluation for ordered categorical data with a threshold model, Génét. Sél. Évol. 15 (1983) 201-224.

[9] Gilmour A.R., Thompson R., Cullis B.R., Average Information REML, an efficient algorithm for variance component estimation in linear mixed models, Biometrics 51 (1995) 1440-1450.

[10] Gilmour A.R., Cullis B.R., Welham S.J., Thompson R., ASREML Reference Manual, New South Wales Agriculture, Orange Agricultural Institute, Australia, 1999.

[11] Hanocq E., Bodin L., Thimonier J., Teyssier J., Malpaux B., Chemineau P., Genetic parameters of spontaneous spring ovulatory activity in Mérinos d'Arles sheep, Genet. Sel. Evol. 31 (1999) 77-90.

[12] Hanarahan J.P., Genetic variation in seasonal reproduction in sheep, in: Proceedings of the 38th Annual Meeting, European Association for Animal Production, Lisbon, Portugal, 1987.

[13] Kouttos A., The spring ovulatory activity as a selection criterion against seasonal reproduction in Chios ewes of Agricultural Station of Chalkidiki, MSc thesis, Faculty of Agriculture, Aristotle University, Thessaloniki, Greece, 2001.

[14] Lewis R.M., Notter D.R., Hogue D.E., Magge B.H., Bergmann J.A.G., Lambing frequency in the star accelerated lambing system, in: Proceedings of the 6th World Congress on Genetics Applied to Livestock Production, 11-16 January 1998, University of New England, Armidale, Australia, pp. 51-54.

[15] Misztal I., Gianola D., Foulley J.L., Computing aspects of a nonlinear method of sire evaluation for categorical data, J. Dairy Sci. 72 (1989) 1557-1568.

[16] Notter D.R., Manipulation of the breeding season by genetic means, in: Burfening P.J., Gabina D. (Eds.), US-Spain Seminar on Sheep Breeding, Zaragoza, Spain, 1986.

[17] Notter D.R., Al-Shorepy S.A., Vincent J.N., McQuown E.C., Selection to improve fertility in fall lambing, in: Proceedings of the 6th World Congress on Genetics Applied to Livestock Production, 11-16 January 1998, University of New England, Armidale, Australia, pp. 43-46.

[18] Oldham C.M., Cognie Y., Do ewes continue to cycle after teasing?, Proc. Aust. Soc. Anim. Prod. 13 (1980) 82-85.

[19] Pelletier J., Bodin L., Hanocq E., Malpaux B., Teyssier J., Thimonier J., Chemineau P., Association between expression of reproductive seasonality and alleles of the gene for $\mathrm{Mel}_{1 \mathrm{a}}$ in the ewe, Biol. Reprod. 62 (2000) 1096-1101.

[20] Quirke J.F., Hanrahan J.P., Loughane W., Triggs R., Components of the breeding and non-breeding seasons in sheep: breed effects and repeatability, Irish J. Agric. Res. 25 (1986) 167-172. 
[21] Robertson A., Lerner I.M., The heritability of all-or-none traits: viability of poultry, Genetics 34 (1949) 395-411.

[22] Tchamitchian L., Choix du moment et de rythme de reproduction, Possibilités de la génétique, in: Proceedings of the 3rd World Congress on Sheep and Beef Cattle Breeding, Paris, 19-23 June, Inra Publ., Paris, 1988, pp. 529-546.

[23] Terqui M., Thimonier J., Nouvelle méthode radio-immunologique rapide pour l'estimation du niveau de progestérone plasmatique. Application pour le diagnostic précoce de gestation chez la brebis et la chèvre (A new, quick radioimmunoassay for the estimation of plasma progesterone levels. Application to pregnancy checks in sheep and goats), C.R. Acad. Sci. Paris, Série D 279 (1974) 1109-1112.

[24] Thimonier J., Mauléon P., Variations saisonnières du comportement d'oestrus et des activités ovariennes et hypophysaires chez les ovins, Ann. Biol. Anim. Bioch. Biophys. 9 (1969) 233-250.

To access this journal online: www.edpsciences.org 